\title{
Id-1 promotes migration and invasion of non-small cell lung cancer cells through activating NF-KB signaling pathway
}

\author{
Jie $\mathrm{Li}^{i^{* \dagger}}$, Yingjie $\mathrm{Li}^{2 \dagger}$, Bin Wang ${ }^{1}$, Yongfu $\mathrm{Ma}^{1}$ and Ping Chen ${ }^{2}$
}

\begin{abstract}
Background: Numerous studies have shown that Id-1 (Inhibitor of differentiation 1) is upregulated in several cancers and associated with tumor malignant characters. However, the clinical significance and biological role of ld-1 in non-small cell lung cancer (NSCLC) remains unclear.

Methods: We used RT-PCR, Western blot and Immunohistochemistry to measure Id-1 expression in NSCLC tissues and matched adjacent noncancerous tissues. The expression pattern of Id-1 in NSCLC tissues was determined by scoring system of immunohistochemical analysis. The Kaplan-Meier method was used to calculate the survival curve, and log-rank test to determine statistical significance. The Id-1 gene was overexpressed or downreuglated with Lentiviral vectors in NSCLC cells. And, the migration ability of NSCLC cells was tested in a Transwell Boyden Chamber.

Results: We found that Id-1 is generally expressed higher in NSCLC tissues compared with matched adjacent noncancerous tissues. We also found that high Id-1 expression in tumor tissues is significantly correlated with tumor progression and poor survival in NSCLC patients. Furthermore, our experimental data revealed that knockdown of Id-1 significantly suppressed the proliferation, migration and invasion of NSCLC cells, whereas ectopic expression of Id-1 promoted the malignant phenotype of NSCLC cells. Mechanistic study showed that NF-KB signaling pathway contributed to the effects of Id-1 in NSCLC cells. Moreover, blocking the NF-kB pathway significantly inhibited the tumor-promoting actions of Id-1 in NSCLC cells.
\end{abstract}

Conclusions: We identified a tumorigenic role of Id-1 in NSCLC and provided a novel therapeutic target for NSCLC patients.

Keywords: Non-small cell lung cancer, Id-1, Migration, Invasion, NF-KB signaling pathway

\section{Introduction}

Lung cancer, predominantly non-small cell lung cancer (NSCLC) is the most commonly diagnosed malignancy, accounting for $\sim 20 \%$ of all cancer-related death worldwide [26]. While remarkable progress during the past decades in diagnose and treatment of NSCLC, but the predicted 5-year survival rate is only around 15\% [7]. And it is mainly a consequence of regional recurrence and lymph node metastasis $[2,12]$. Thus, a better understanding of the molecular mechanism involved in the

\footnotetext{
* Correspondence: lijieefy186@163.com

${ }^{\dagger}$ Equal contributors

'Department of Chest Surgery, The General Hospital of The People's

Liberation Army, No. 28 Fuxing road, Beijing 100853, China

Full list of author information is available at the end of the article
}

development and progression of NSCLC is urgently needed.

Inhibitor of differentiation 1 (Id-1), a class of dominantnegative antagonists of helix-loop-helix transcription factors, has multiple functions including inhibition of differentiation, induction of proliferation, and delaying replicative senescence [22, 29]. Recently, Id-1 has been suggested as a potential oncogene, as aberrant elevation of Id-1 has been found in numerous types of cancers such as cervical [24], osteosarcoma [9] and prostate cancers [8]. In osteosarcoma and cervical cancer patients, high Id-1 expression is correlated with more aggressive behavior as well as much shorter overall survival $[9,24]$. Furthermore, Id-1 has been reported to promote survival and metastatic ability of cancer cells. For 
instance, Id-1 enhances invasive properties of hematopoietic cell lines through transactivation of MMP9 [21]. In addition, Id-1-induced transforming growth factor- $\beta$-induced epithelial-mesenchymal transition [14], and also enhanced cell migration in breast cancer [25]. Although Id-1 has been extensively investigated in recent years, the functions and mechanisms of Id-1 in NSCLC development remain unclear.

In the present study, we found that Id-1 overexpression is significantly correlated with tumor progression and poor survival in NSCLC patients. Gain and loss of function assays found that Id-1 promoted migration, invasion and viability of NSCLC cells by in vitro experiments. Mechanistic study showed that the tumorigenic role of Id-1 in NSCLC is at least partly via activation of NF- $\mathrm{kB}$ signaling pathway. Therefore, our results identify Id-1 as a novel regulator of NSCLC invasiveness and may provide a promising therapeutic strategy for treatment of NSCLC patients.

\section{Methods}

\section{Patients and tumor specimens}

Matched cancerous and noncancerous tissues were obtained from 96 patients with NSCLC in the Department of General surgery, The General Hospital of The People's Liberation Army, immediately snap-frozen in liquid nitrogen, and stored at $-80{ }^{\circ} \mathrm{C}$ for $\mathrm{RNA}$ and protein extraction. A pathologist confirmed that all the specimens were derived from normal tissues. Informed consent was obtained from the patients, and the research procedure was approved by the Ethics Committee of The General Hospital of The People's Liberation Army.

\section{Cell lines and cell culture}

A total of five cell lines were used including four NSCLC cell lines (H226, H292, H460 and A549) and the immortalized normal human bronchial epithelial cell line (BEAS-2B). NSCLC cells were maintained in RPMI-1640 (HyClone) supplemented with 10\% FBS (Gibco) and antibiotics $(100 \mathrm{U} / \mathrm{ml}$ penicillin and $100 \mathrm{mg} / \mathrm{ml}$ streptomycin) (Invitrogen). BEAS-2B cells were maintained in BEGM (Lonza). All cell lines were maintained in an incubator with a humidified atmosphere of $95 \%$ air and $5 \% \mathrm{CO}_{2}$ at $37{ }^{\circ} \mathrm{C}$.

\section{RNA extraction and quantitative real-time PCR (qRT-PCR)}

The relative RNA levels of genes were assessed by quantitative real-time PCR. In brief, total RNA was isolated with the standard TRIzol-based protocol (Invitrogen, USA). RNA was reverse transcribed using the PrimeScript RT Reagent Kit (Invitrogen, USA) and qPCR was performed using SYBR Premix Ex Taq (TaKaRa, China), following the manufacturer's instructions. The genespecific primers were as follows: GAPDH (sense: 5'CTGGGCTACACTGAGCACC-3', antisense: 5'-AAGT
GGTCGTTGAGGGCAATG-3'), Id-1 (sense: 5'-CCAGC ACGTCATCGACTAC-3', antisense: 5' - GCTTCAGCG ACACAAGATG-3').

\section{Western blot assay}

Western blot analysis for specific protein expression was performed as previously described [32], while, cytoplasmic and nuclear protein were isolated and purified using the Protein and RNA Isolation System (Life technologies) according to the manufacturer's instructions. The antibodies used were as follows: anti-Id-1 (1:500, Santa Cruz, USA), anti-p-IkB $\alpha$ (1:1000, CST), anti-IkB $\alpha$ (1:1000, CST), anti-p65 (1:1000, CST), anti- Histone 3 (1:1000, Abcam), anti-E-cadherin (1:1000, CST), anti- $\mathrm{N}$-cadherin $(1: 1000$, CST) and anti- $\beta$-Actin (1:1000, Santa Cruz, USA). The signals were detected by enhanced chemiluminescence (Pierce, USA).

\section{Immunohistochemistry (IHC) staining}

The NSCLC and normal lung tissues were fixed, embedded, sectioned, and deparaffinized. Some of the deparaffinized sections were stained with $H \& E$ staining. IHC staining was performed using a Dako Envision System (Dako, USA) following the manufacturer's protocol. Sections were blocked using serum-free protein block buffer (DAKO, CA, USA) for $30 \mathrm{~min}$, after which they were incubated with anti-Id-1 (1:200, Santa Cruz, USA).

\section{Stable cell lines construction}

Full-length human Id-1 cDNA was compounded by Genechem and ligated into pENTR221 vector (Genechem, Shanghai). An empty vector was used as the negative control. The Id-1 knockdown was achieved by RNA interference using a lentiviral vector-based shRNA (Genechem, Shanghai). Lentiviral particles corresponding to the shRNA Id-1 NM_002165 target set were used, as well as a nontarget shRNA control. The shRNA sequences were as follows: Id-1 shRNA, CGTGCTCTGTGGGTCTC. For the generation of stable cell lines, Lv-Id-1 or sh-Id-1 was transfected into the NSCLC cells, and selected with puromycin. Specificity and efficacy of the lentivirus were evaluated by Western blotting after transduction and puromycin selection in cells.

\section{Cell proliferation assays}

To examine cell proliferation, $5 \times 10^{3}$ cells/well were seeded in a 96-well plate and cultured in a $5 \% \mathrm{CO}_{2}$ incubator at $37{ }^{\circ} \mathrm{C}$. At the indicated time points, viable cells were counted using the Cell Counting Kit- 8 according the manufacturer's protocol.

\section{Colony formation assay}

Cells were seeded in 6-well plates at a density of 1000 cells per well. After incubation for 14 days, the 
supernatant was discarded and cells were washed twice in phosphate-buffered saline (PBS). Then, cells were fixed in $10 \%$ methanol for $15 \mathrm{~min}$ and stained with Giemsa for $20 \mathrm{~min}$. Colonies consisting of more than 50 cells were scored, and the rate of colony formation was calculated.

\section{Cell migration and invasion assay}

The migration ability of NSCLC cells was tested in a Transwell Boyden Chamber (8-mm pore size, BD Biosciences) as previously described [10]. For the cell invasion assay, the polycarbonate membranes of the upper compartment of the chambers were precoated with a matrix gel.

\section{Immunofluorescent analysis}

The Cells $\left(5 \times 10^{3}\right)$ were implanted onto a slide for $24 \mathrm{~h}$, and then were fixed with paraformaldehyde for $30 \mathrm{~min}$, followed permeabilizing with $0.3 \%$ Triton X-100/PBS for $5 \mathrm{~min}$ at room temperature. Then, cells were blocked with $5 \%$ BSA for $1 \mathrm{~h}$ at room temperature and stained with antiE-cadherin (1:200, CST) and anti-N-cadherin (1:200, CST) at $4{ }^{\circ} \mathrm{C}$ overnight, followed by incubation with fluorescentdye conjugated secondary antibody (1:200, Invitrogen) for $1 \mathrm{~h}$, and then stained with DAPI. Fluorescence images were photographed with a confocal microscope.

\section{Statistical analysis}

All data are expressed in terms of means \pm the SEM. Significant differences were analyzed using Student's t- test and two-tailed distribution. The Kaplan-Meier method was used to calculate the survival curve, and log-rank test to determine statistical significance. $P$ values $<0.05$ were considered statistically significant.

\section{Results}

Id-1 is upregulated in tumor tissues and closely correlated with clinical outcomes of patients with NSCLC To investigate the potential role of Id-1 in NSCLC development, we firstly measured the expression of Id-1 in paired tumor tissues and matched adjacent noncancerous tissues from 96 patients with NSCLC using qRTPCR. As shown in Fig. 1a, the expression of Id-1 was significantly upregulated in tumor tissues compared with the adjacent noncancerous tissues in these 96 NSCLC patients. Furthermore, we randomly selected four tissue samples of NSCLC and paired normal lung according to the results of qRT-PCR analysis to analyze the expression of Id-1 protein. Consistently, the results showed that the expression of Id-1 protein was also enhanced in NSCLC tissues in comparison with the adjacent noncancerous tissues by western blot assay (Fig. 1b). Moreover, these findings were confirmed by detecting Id-1 protein expression by immunohistochemical (IHC) staining. As shown in Fig. 1c, the data revealed that Id-1 was overexpressed in 61.5\% (59/96) NSCLC specimens detected.

Next, we analyzed associations between Id-1 expression and clinicopathological parameters in NSCLC patients detected (Table 1). The results showed that the
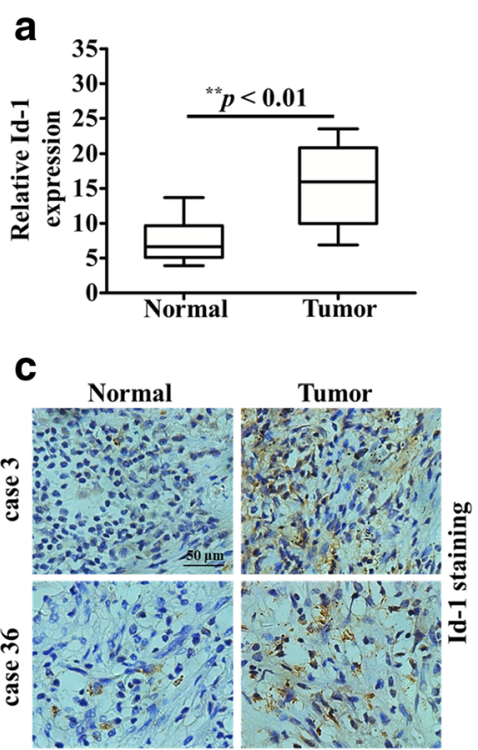

b

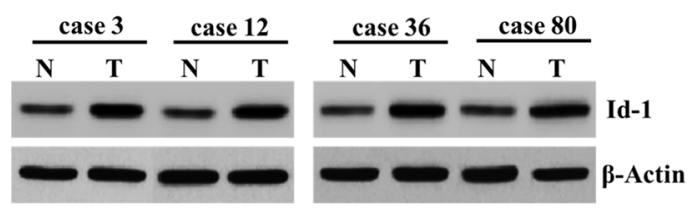

d

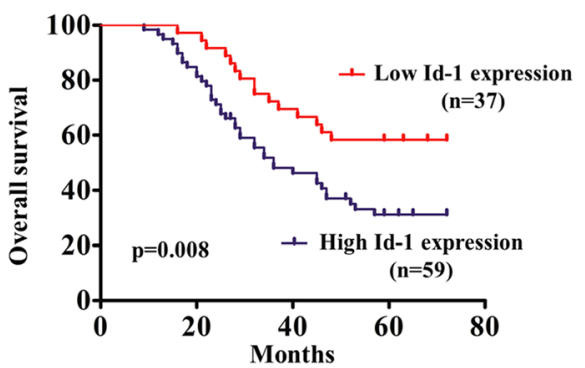

Fig. 1 Relative Id-1 expression in NSCLC clinical samples, and its clinical significance. a Relative mRNA levels of Id-1 in NSCLC tissues and in paired noncancerous tissues. Id-1 expression was examined by qPCR and normalized to GAPDH expression. ${ }^{* *} P<0.01$, compared with non-tumor counterpart. b Western blot of Id-1 protein quantification in 4 NSCLC tissues and in paired noncancerous tissues. $\beta$-Actin was a loading control. c Representative images of Id-1 staining in 96 paired NSCLC tissues. Scale bar, $50 \mu \mathrm{m}$. d Kaplan-Meier curves for overall survival of two groups defined by high and low expression of $1 \mathrm{~d}-1$ in patients with NSCLC. ${ }^{* *} p=0.008$ 
Table 1 The relationship between ld-1 expression and clinicopathological factors in 96 NSCLC patients

\begin{tabular}{|c|c|c|c|c|}
\hline \multirow{2}{*}{$\begin{array}{l}\text { Pathological } \\
\text { characteristics }\end{array}$} & \multirow{2}{*}{$\begin{array}{l}\text { No. } \\
96\end{array}$} & \multicolumn{2}{|c|}{ Id-1 expression } & \multirow[t]{2}{*}{$P$ value } \\
\hline & & High, $n$ & $\overline{\text { Low, } \mathrm{n}}$ & \\
\hline \multicolumn{5}{|l|}{ Age, years } \\
\hline$\leq 55$ & 45 & 30 & 15 & \\
\hline$>55$ & 51 & 29 & 22 & 0.325 \\
\hline \multicolumn{5}{|l|}{ Gender } \\
\hline Male & 57 & 39 & 18 & \\
\hline Female & 39 & 20 & 19 & 0.090 \\
\hline \multicolumn{5}{|l|}{ Tumor size $(\mathrm{cm})$} \\
\hline$\leq 3.5$ & 41 & 20 & 21 & \\
\hline$>3.5$ & 55 & 39 & 16 & $0.028^{*}$ \\
\hline \multicolumn{5}{|l|}{ TNM stage } \\
\hline$|-| \mid$ & 46 & 35 & 11 & \\
\hline $\mathrm{III-IV}$ & 50 & 24 & 26 & $0.005^{* *}$ \\
\hline \multicolumn{5}{|l|}{ Smoking history } \\
\hline No & 38 & 26 & 12 & \\
\hline Yes & 58 & 33 & 25 & 0.257 \\
\hline \multicolumn{5}{|l|}{ Lymph node metastasis } \\
\hline Negative & 40 & 19 & 21 & \\
\hline Positive & 56 & 40 & 16 & $0.018^{*}$ \\
\hline \multicolumn{5}{|l|}{ Histopathologic type } \\
\hline Adenocarcinoma & 41 & 23 & 18 & \\
\hline Non-adenocarcinoma & 55 & 36 & 19 & 0.351 \\
\hline
\end{tabular}

upregulation of Id-1 were significantly associated with larger tumor size $(p=0.028)$, lymph node metastasis $(p=0.018)$ and advanced TNM stage $(p=0.005)$. In addition, the Kaplan-Meier survival curves (Fig. 1d) revealed that high level of Id-1 expression had a shorter survival time than patients who had low level of Id-1 expression $(n=96, p=0.008)$. Taken together, these findings suggest that the expression of Id-1 was significantly upregulated in NSCLC tissues and implicated in the progression of NSCLC.

\section{Id-1 promotes cell viability, migration and invasion of NSCLC cells}

To further explore the biological function of Id-1 in NSCLC, we initially measured the expression level of Id-1 in four NSCLC cell lines (A549, H460, H292 and H226) and human bronchial epithelial cell line (BEAS-2B). As shown in Fig. 2a, the expression of Id1 was significantly higher in four NSCLC cells than compared with BEAS-2B cell. Interestingly, the expression of Id-1 was much higher in NSCLC cell lines derived from metastatic sites than that derived from primary sites (Fig. 2a). Then, we knocked down
Id-1 by stably expressing Id-1 shRNA in H226 cells, which normally show relatively high Id-1 expression (Fig. 2a). Meanwhile, we developed stable clones with Id-1 overexpression from A549 cell, which exhibit relatively low expression of Id-1 among NSCLC cell lines (Fig. 2a).

Next, we examined the effects of Id-1 on the NSCLC cell's viability and metastasis. Our results show that H226/sh-Id-1 cells showed a significantly lower in vitro proliferation rate than control cells (Fig. 2b). Conversely, the overexpression of Id-1 significantly increased cell viability of A549 cell (Fig. 2c). Meanwhile, knockdown of Id-1 resulted in a substantial decrease in H226 cell growth in comparison with control groups, whereas overexpression of Id-1 promotes the proliferation of A549 cells by colony formation assay (Fig. $2 \mathrm{~d}$ and e).

In addition, we investigated the effect of Id-1 on migration and invasion of NSCLC cells. The results demonstrated that knockdown of NSCLC significantly suppressed the cell migration and invasion capability of H226 cells (Fig. 2f), whereas overexpression of Id-1 promoted migration and invasion ability of A549 cells (Fig. 2g). It is well known that EMT is the remarkable presentation for cell metastasis, whether Id-1 knockdown reverse the EMT phenotype need to be identified. As showed in Fig. 2h, western blot revealed that $\mathrm{N}$ cadherin was downregulated after Id-1 knockdown, while E-cadherin was increased in H226 cells. Immunofluorescence assays also confirmed that downregulation of Id-1 increased the epithelial marker but decreased the mesenchymal maker in H226 cells (Fig. 2i). Therefore, these results demonstrated that downregulation of Id-1 inhibited NSCLC cell migration and invasion by suppressing the EMT.

\section{Id-1 enhances IKBa phosphorylation and NF-KB activation in NSCLC cells}

To elucidate the underlying mechanism of Id-1-mediated tumorigenesis of NSCLC, we examined the activation of multiple signaling pathways. Among the pathways we screened, the NF- $\mathrm{kB}$ signaling pathway was found to be involved in Id-1-mediated function. We found that the phosphorylation level of IкB $\alpha$ was significantly reduced in Id-1-knockdown cells, whereas it was elevated in Id-1overexpressing cells (Fig. 3a). Furthermore, we measured the phosphorylation level of I $\kappa \mathrm{B} \alpha$ (activation of NF- $\kappa B$ signaling pathway) in NSCLC tissues, which exhibited high Id-1 protein expression. Our results indicate that the

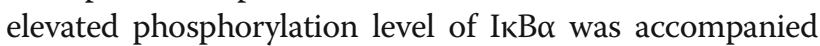
with high Id-1 expression in NSCLC tissues, when compared with corresponding non-tumor tissues (Fig. 3b). Moreover, Id-1 expression was positively correlated with phosphorylation level of IkB $\alpha$ in NSCLC tissues (Fig. 3c).

Next, we detected the effect of Id-1 on the activation of NF-kB in NSCLC cells. As shown in Fig. 3d, 


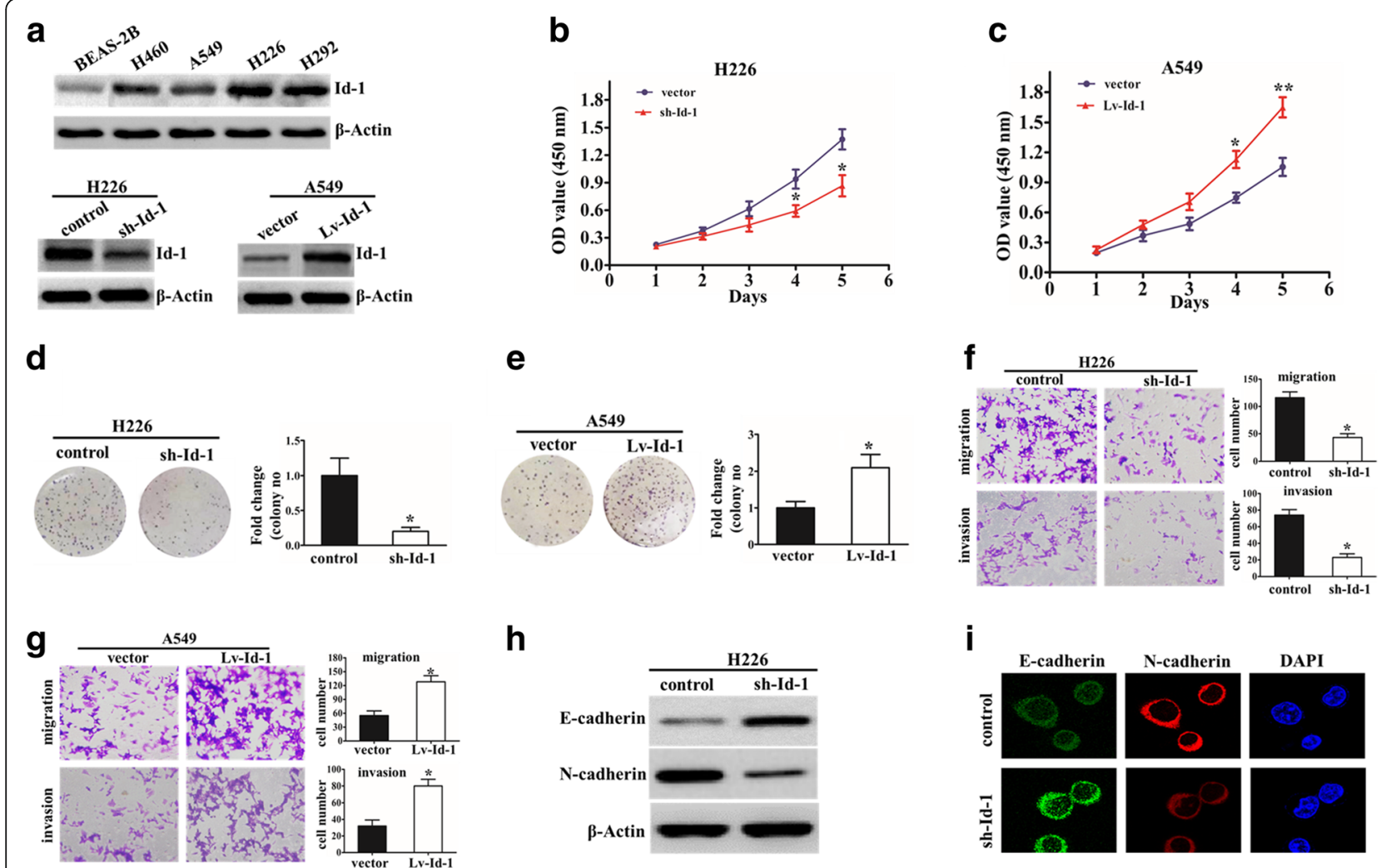

Fig. 2 Id-1 was associated with viability and mobility features of NSCLC cell. a Determination of Id-1 expression levels in four NSCLC cell lines and the immortalized normal human bronchial epithelial cell line (BEAS-2B). The efficiency of Id-1 silencing and overexpression in NSCLC cell lines was measured by Western blot. $\beta$-Actin was a loading control. $\mathbf{b}$ and $\mathbf{c}$ Representative results for cell proliferation rate were evaluated in Id1-knockdown (b) or Id-1-overexpressing (c) NSCLC cells by using CCK-8 assay. ${ }^{*} p<0.05,{ }^{* *} p<0.01$. $\mathbf{d}$ and $\mathbf{e}$, Representative images (left) and quantification (right) of the clone formation assays are shown in ld-1-knockdown (d) or ld-1-overexpressing (e) NSCLC cells. " $p<0.05$, compared with control groups. F and G, Representative results (right) and Quantification (left) of the migration and invasion showing the effect of Id-1 knockdown (f) or Id-1 overexpression $(\mathbf{g})$ on the migratory abilities of NSCLC cells. ${ }^{*} p<0.05$. $\mathbf{h}$ Western blot analysis of the phenotypic markers, including E-cadherin and N-cadherin in Id-1 silencing cells. $\beta$-Actin was used as the loading control. i Confocal microscopy analysis of the E-cadherin and N-cadherin. The red and green signal represents the staining of the corresponding protein, and the blue signal represents the nuclear DNA staining by DAPI

overexpression of Id-1 significantly improved the nuclear translocation of p65. Moreover, TNF- $\alpha(10 \mathrm{ng} / \mathrm{ml})$ was used to induce the NF- $\mathrm{kB}$ activation in Id-1-knockdown cells. The results showed that knockdown of Id-1 led to significant cytoplasm retention of p65 after TNF- $\alpha$ treatment compared with control groups (Fig. $3 e$ and f). Therefore, these findings suggest that Id-1 promoted phosphorylation of ІкB $\alpha$ and p65 nuclear translocation in NSCLC cells.

\section{Id-1 promotes migration and invasion of NSCLC cells through NF-KB signaling pathway}

To further evaluate whether NF- $\mathrm{kB}$ signaling pathway is responsible for NSCLC cell migration and invasion regulated by Id-1, we performed rescue experiments by treatment with NF- $\mathrm{kB}$ activator TNF- $\alpha$ and NF- $\mathrm{kB}$ translocation inhibitor JSH-23. As shown in Fig. 4a and $\mathrm{b}$, the increased cell migration and invasion ability induced by TNF- $\alpha$ in H226 cells was partly abolished by
Id-1 knockdown. Then, we examined the phosphoryl-

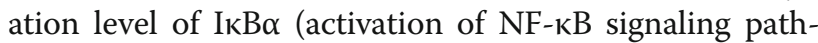
way) in present of inhibitor JSH-23. As shown in Fig. 4c, the elevated phosphorylation level of ІкB $\alpha$ was abolished in A549 cells after treatment with inhibitor JSH-23. As expected, the upregulation of Id-1 significantly improved the migration and invasion capacity of A549 cells, which was significantly abrogated by NF- $\mathrm{KB}$ translocation inhibitor JSH-23 (Fig. 4d and e). Collectively, all these results suggested that NF- $\mathrm{kB}$ pathway acts as the downstream component of Id-1 and contributes to the effects of Id-1 in NSCLC cells.

\section{Discussion}

Id-1 has been reported to be upregulated and identified as a potential tumor promoter in diverse cancers, including hepatocellular carcinoma and breast cancer [6, 31]. However, it is worth noting that the underlying biological role of Id-1 in NSCLC is still unknown. Here, our findings 

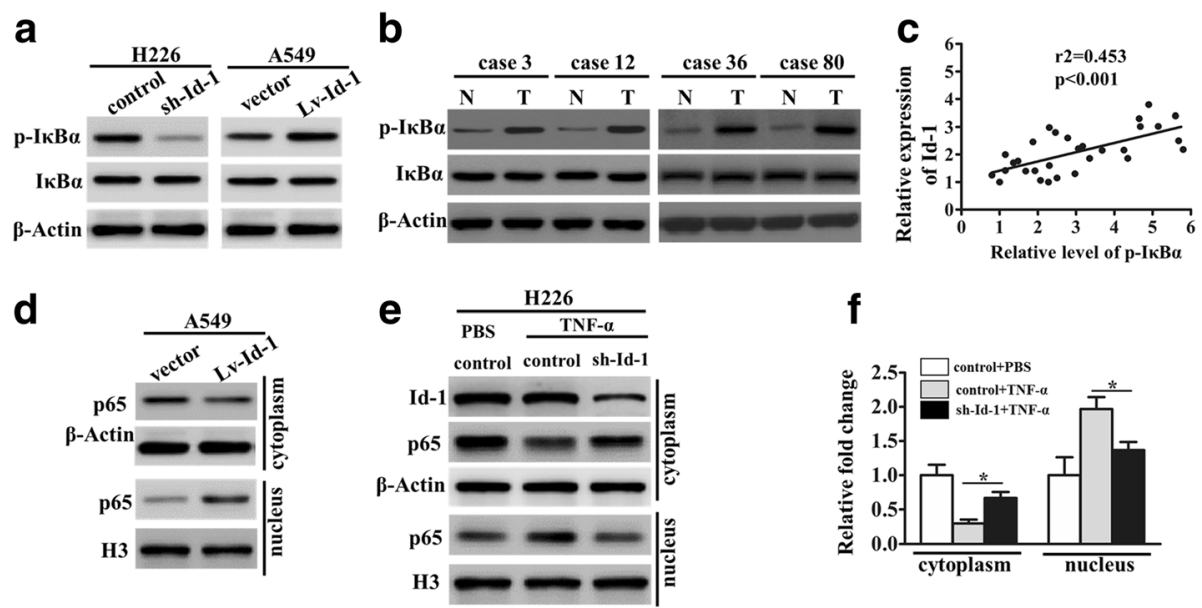

Fig. 3 Id-1 positively regulate IKB phosphorylation and NF-KB activation in NSCLC cells. a, Western blotting showing total and phosphorylated IKBa in Id-1-silenced H226 cells and Id-1-overexpressing A549 cells. $\beta$-Actin was a loading control. b. Western blotting showing total and phosphorylated IKBa in NSCLC tissues. $\beta$-Actin was a loading control. c, Scatter plots showing the positive linear correlation between the Id-1 expression and phosphorylation level of $\mathrm{IkBa}$ in NSCLC tissues. d, Western blot for nuclear and cytoplasm p65 in Id-1-overexpressing A549 cells. $\beta$-Actin and Histone $3(\mathrm{H} 3)$ is the loading control for cytoplasm and nuclear, respectively. e, Western blot for Id-1, nuclear and cytoplasm p65 in ld-1- silenced H226 cells after incubation with TNF-a $(10 \mathrm{ng} / \mathrm{ml})$ for $24 \mathrm{~h}$. $\beta$-Actin and Histone 3 (H3) is the loading control for cytoplasm and nuclear, respectively. $\mathbf{f}$, Graphic presentation of the relative abundances (fold induction versus the controls). ${ }^{*} P<0.05$ versus control groups after TNF-a treatment

showed that Id-1 expression remarkable increase in NSCLC tissues compared to the corresponding nontumor tissues. Importantly, we revealed that high expression level of Id-1 is closely associated with tumor size, high stage, lymph node metastasis, and as an independent risk factor to predict overall survival. These data indicated that high Id-1 expression may represent a novel indicator of poor prognosis in NSCLC and may function as an oncogene in NSCLC progression.

Increasing evidence has demonstrated that Id-1 is involved in the regulation of cancer cell proliferation. Hao et al. have reported that Id-1 promotes osteosarcoma cell growth and inhibits cell apoptosis via PI3K/AKT signaling pathway [9]. Additionally, Id-1 induces ESCC cell

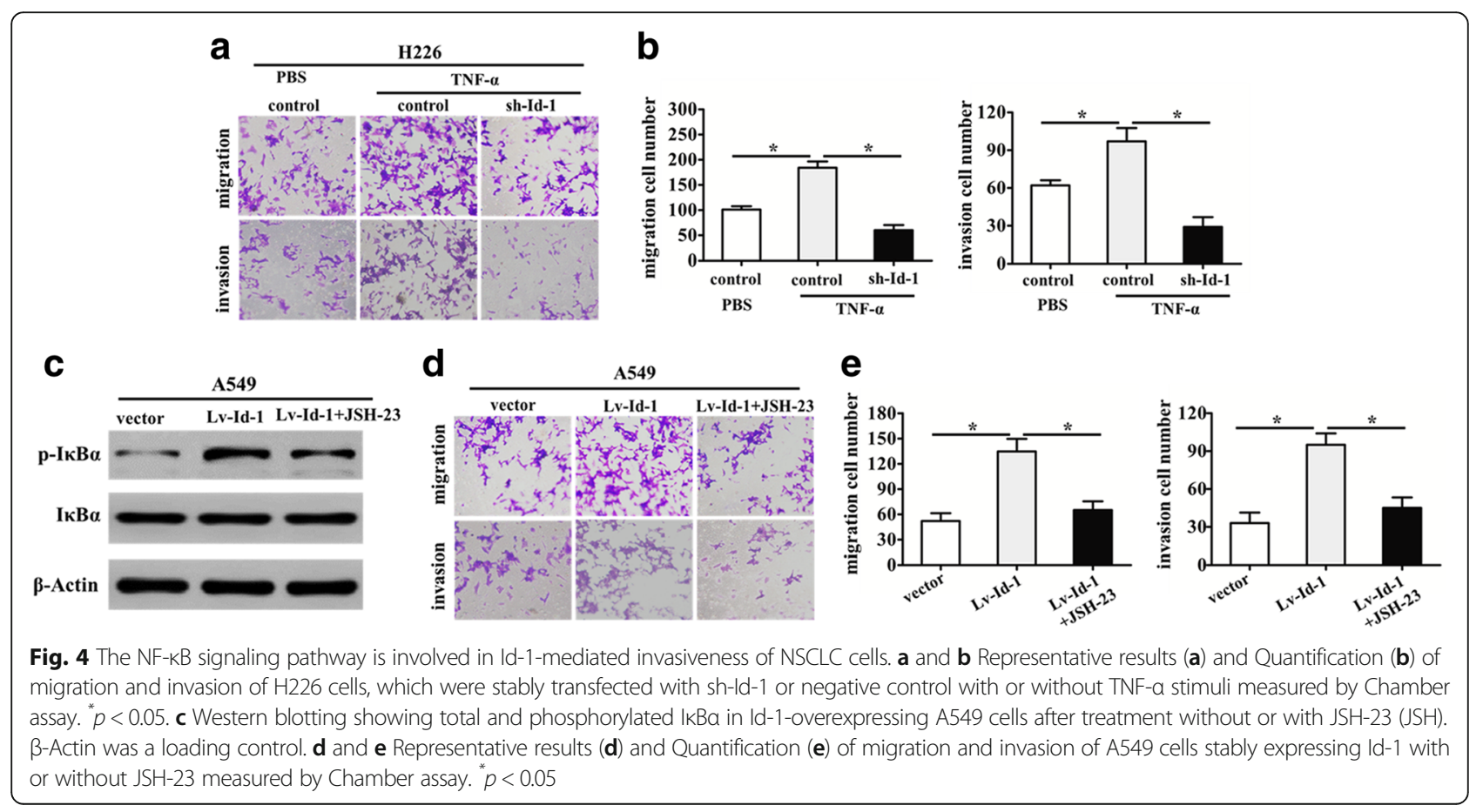


proliferation may be through inactivation of $\mathrm{p} 16^{\mathrm{INK} 4 \mathrm{~A}} /$ RB pathway [13]. In present study, our experimental data revealed that overexpression of Id-1 significantly enhanced cell proliferation by activation of NF-KB signaling pathway in NSCLC cells. Based on these results, we suggest that the downstream signaling pathways of Id-1-mediated cell proliferation may differ between cancer types.

It is known that metastasis is one of the major characteristics in many cancers, and is associated with cancer progression $[27,30]$. Previous studies have demonstrated that Id-1 is suggested to play a critical role during invasion and metastasis in various cancers [11, 18]. For example, Id-1 silencing significantly suppressed the gastric cancer cell migration and invasion in vitro [18]. Cao Y. et al. have reported that fucoidan-induced Id-1 suppression inhibited the in vitro and in vivo invasion of hepatocellular carcinoma cells [4]. Consistent with these studies, our experimental data revealed that downregulation of Id-1 also inhibited migratory ability of NSCLC cells. Thus, these findings suggest that Id- 1 would be a potential anti-metastasis therapeutic target for NSCLC patients.

Since Id-1 is a regulator of transcription, it may be responsible for regulation of gene expression involving multiple transduction pathways. So far, several signaling pathways have been suggested to mediate the tumorigenic effects of Id-1 $[15,23]$. Id- 1 has been shown to promote cell survival by activating NF- $\mathrm{kB}$ signaling pathway and it has been suggested that it may be one of the upstream regulators of NF-kB in various cancer $[16,17]$. Consistent with this findings, we also found that the NF$\mathrm{\kappa B}$ signaling pathway is responsible for Id-1-mediated tumor cell migration and invasion. As a transcription factors, NF- $\mathrm{kB}$ regulates many downstream genes expression including that regulate cell metastasis and plays pivotal roles in both promoting and maintaining an invasive phenotype $[3,20]$. Especially, a lots of evidence showed that NF- $\mathrm{KB}$ signaling pathway activates the expression of genes important for the progression of NSCLC [5]. For instance, Foxp3 downregulation in NSCLC mediates epithelial-mesenchymal transition via NF- $\mathrm{kB}$ signaling pathway [28]. The major finding of this study is that the oncogenic effect of Id-1 is through activation of NF- $\mathrm{KB}$ signaling pathway leading to promotion of metastasis in NSCLC cells. On the basis of these findings, Id-1 could be a promising new therapeutic target for suppression the metastasis of NSCLC. Additionally, a previous study agreed with these conclusions revealing that Id-1 is able to protect anticancer drug induced apoptosis through activation of NF- $\mathrm{kB}$ pathways in prostate cancer [17]. The NF-kB inhibitor JSH-23 has been evaluated for antitumor activity in a variety of preclinical cancer models [1, 19], but has not been extended to
NSCLC. Here, we found that blocking NF- $\mathrm{kB}$ signaling pathway using JSH-23 attenuated the Id-1-induced tumor cell metastasis, provide novel evidence to support further explorations into the use of NF- $\mathrm{BB}$ inhibitors in NSCLC cancer therapy. Taken together, the tumorpromoting effects of Id-1 in NSCLC cells is at least partly through activation of NF- $\mathrm{kB}$ signaling pathway.

\section{Conclusions}

In summary, our data revealed that Id-1 was upregulated in NSCLC tissues and cell lines. We also exhibited that Id-1 may be a potential inducement in NSCLC invasiveness though activation of NF- $\mathrm{kB}$ signaling pathway. On the basis of these findings, Id- 1 could be a promising new therapeutic target for suppression the metastasis of NSCLC.

\section{Acknowledgements \\ Not applicable. \\ Funding \\ Not applicable. \\ Availability of data and materials \\ Not applicable.}

Authors' contributions

J. L. and Y. L. conceived and designed the study. J. L., B.W., Y. M., and P. C. performed the experiments. J. L. wrote the paper. J. L. and Y. L. reviewed and edited the manuscript. All authors read and approved the final manuscript.

\section{Ethics approval and consent to participate}

Informed consent was obtained from the patients, and the research procedure was approved by the Ethics Committee of The General Hospital of The People's Liberation Army.

Consent for publication

All authors have read and agreed to the final version of the manuscript.

Competing interests

The authors declare that they have no competing interests.

\section{Publisher's Note}

Springer Nature remains neutral with regard to jurisdictional claims in published maps and institutional affiliations.

\section{Author details}

${ }^{1}$ Department of Chest Surgery, The General Hospital of The People's Liberation Army, No. 28 Fuxing road, Beijing 100853, China. ${ }^{2}$ Department of Cardio-thoracic Surgery, First Affiliated Hospital, General Hospital of The People's Liberation Army, Beijing, China.

Received: 11 August 2017 Accepted: 1 December 2017

Published online: 12 December 2017

\section{Reference}

1. Ahmed KM, Zhang H, Park CC. Nf-kappab regulates radioresistance mediated by beta1-integrin in three-dimensional culture of breast cancer cells. Cancer Res. 2013;73(12):3737-48. https://doi.org/10.1158/0008-5472. can-12-3537.

2. Burrell RA, McGranahan N, Bartek J, Swanton C. The causes and consequences of genetic heterogeneity in cancer evolution. Nature. 2013; 501(7467):338-45. https://doi.org/10.1038/nature12625.

3. Chandrika G, Natesh K, Ranade D, Chugh A, Shastry P. Suppression of the invasive potential of glioblastoma cells by mtor inhibitors involves 
modulation of nfkappab and pkc-alpha signaling. Sci Rep. 2016;6:22455. https://doi.org/10.1038/srep22455.

4. Cho Y, Cho EJ, Lee JH, Yu SJ, Kim YJ, Kim CY, Yoon JH. Fucoidaninduced id-1 suppression inhibits the in vitro and in vivo invasion of hepatocellular carcinoma cells. Biomed Pharmacother. 2016;83:607-16. https://doi.org/10.1016/j.biopha.2016.07.027.

5. Denlinger CE, Rundall BK, Jones DR. Modulation of antiapoptotic cell signaling pathways in non-small cell lung cancer: the role of nf-kappab. Semin Thorac Cardiovasc Surg. 2004;16(1):28-39.

6. Ding R, Han S, Lu Y, Guo C, Xie H, Zhang N, Song Z, Cai L, Liu J, Dou K. Overexpressed id-1 is associated with patient prognosis and hbx expression in hepatitis b virus-related hepatocellular carcinoma. Cancer Biol Ther. 2010;10(3):299-307.

7. Ettinger DS, Wood DE, Akerley W, Bazhenova LA, Borghaei H, Camidge DR, Cheney RT, Chirieac LR, D'Amico TA, Demmy TL, Dilling TJ, Govindan R, Grannis FW Jr, Horn L, Jahan TM, Komaki R, Kris MG, Krug LM, Lackner RP, Lanuti M, Lilenbaum R, Lin J, Loo BW Jr, Martins R, Otterson GA, Patel JD, Pisters KM, Reckamp K, Riely GJ, Rohren E, Schild S, Shapiro TA, Swanson SJ, Tauer K, Yang SC, Gregory K, Hughes M. Non-small cell lung cancer, version 1.2015. J Natl Compr Cancer Netw. 2014;12(12):1738-61.

8. Forootan SS, Wong YC, Dodson A, Wang X, Lin K, Smith PH, Foster CS, Ke Y. Increased id-1 expression is significantly associated with poor survival of patients with prostate cancer. Hum Pathol. 2007;38(9):1321-9. https://doi. org/10.1016/.humpath.2007.02.011.

9. Hao L, Liao Q, Tang Q, Deng H, Chen L. Id-1 promotes osteosarcoma cell growth and inhibits cell apoptosis via pi3k/akt signaling pathway. Biochem Biophys Res Commun. 2016a;470(3):643-9. https://doi.org/10.1016/j.bbrc. 2016.01.090

10. He D, Li L, Zhu G, Liang L, Guan Z, Chang L, Chen Y, Yeh S, Chang C. Asc-j9 suppresses renal cell carcinoma progression by targeting an androgen receptor-dependent hif2alpha/vegf signaling pathway. Cancer Res. 2014; 74(16):4420-30. https://doi.org/10.1158/0008-5472.can-13-2681.

11. Hu H, Wang YL, Wang GW, Wong YC, Wang XF, Wang Y, Xu KX. A novel role of id-1 in regulation of epithelial-to-mesenchymal transition in bladder cancer. Urol Oncol. 2013;31(7):1242-53. https://doi.org/10.1016/j.urolonc. 2011.12.003.

12. Huang YT, Heist RS, Chirieac LR, Lin X, Skaug V, Zienolddiny S, Haugen A, Wu MC, Wang Z, Su L, Asomaning K, Christiani DC. Genome-wide analysis of survival in early-stage non-small-cell lung cancer. J Clin Oncol. 2009; 27(16):2660-7. https://doi.org/10.1200/jco.2008.18.7906.

13. Hui CM, Cheung PY, Ling MT, Tsao SW, Wang X, Wong YC, Cheung AL. Id-1 promotes proliferation of p53-deficient esophageal cancer cells. International journal of cancer. J Int Cancer. 2006;1 19(3):508-14. https://doi. org/10.1002/ijc.21874.

14. Kondo M, Cubillo E, Tobiume K, Shirakihara T, Fukuda N, Suzuki H, Shimizu K, Takehara K, Cano A, Saitoh M, Miyazono K. A role for id in the regulation of tgf-beta-induced epithelial-mesenchymal transdifferentiation. Cell Death Differ. 2004:11(10):1092-101. https://doi.org/10.1038/sj.cdd.4401467.

15. Lee JY, Kang MB, Jang SH, Qian T, Kim HJ, Kim CH, Kim Y, Kong G. Id-1 activates akt-mediated wnt signaling and p27(kip1) phosphorylation through pten inhibition. Oncogene. 2009;28(6):824-31. https://doi.org/10. 1038/onc.2008.451.

16. Li B, Cheung PY, Wang X, Tsao SW, Ling MT, Wong YC, Cheung AL. Id-1 activation of pi3k/akt/nfkappab signaling pathway and its significance in promoting survival of esophageal cancer cells. Carcinogenesis. 2007;28(11): 2313-20. https://doi.org/10.1093/carcin/bgm152.

17. Ling MT, Wang X, Ouyang XS, Xu K, Tsao SW, Wong YC. Id-1 expression promotes cell survival through activation of nf-kappab signalling pathway in prostate cancer cells. Oncogene. 2003;22(29):4498-508. https://doi.org/10. 1038/sj.onc.1206693.

18. Ma H, Wei Y, Leng Y, Li S, Gao L, Hu H, Chen L, Wang F, Xiao H, Zhu C, Liang C. Tgf-beta1-induced expression of id-1 is associated with tumor progression in gastric cancer. Med Oncol (Northwood, London, England). 2014;31(7):19. https://doi.org/10.1007/s12032-014-0019-3.

19. Miao C, Ma J, Zhang Y, Chu Y, Li J, Kuai R, Wang S, Peng H. Perfluorooctanoic acid enhances colorectal cancer dld-1 cells invasiveness through activating nf-kappab mediated matrix metalloproteinase-2/-9 expression. Int J Clin Exp Pathol. 2015;8(9):10512-22.
20. Mitchell S, Vargas J, Hoffmann A. Signaling via the nfkappab system. Wiley interdisciplinary reviews. Syst Biol Med. 2016;8(3):227-41. https://doi.org/10. 1002/wsbm.1331.

21. Nieborowska-Skorska M, Hoser G, Rink L, Malecki M, Kossev P, Wasik MA, Skorski T. Id 1 transcription inhibitor-matrix metalloproteinase 9 axis enhances invasiveness of the breakpoint cluster region/abelson tyrosine kinase-transformed leukemia cells. Cancer Res. 2006;66(8):4108-16. https:// doi.org/10.1158/0008-5472.can-05-1584.

22. Perk J, lavarone A, Benezra R. Id family of helix-loop-helix proteins in cancer. Nature reviews. Cancer. 2005;5(8):603-14. https://doi.org/10.1038/nrc1673.

23. Qiu J, Wang G, Peng Q, Hu J, Luo X, Zheng Y, Teng Y, Tang C. Id1 induces tubulogenesis by regulating endothelial cell adhesion and cytoskeletal organization through beta1-integrin and rho-kinase signalling. Int J Mol Med. 2011;28(4):543-8. https://doi.org/10.3892/ijmm.2011.741.

24. Schindl M, Oberhuber G, Obermair A, Schoppmann SF, Karner B, Birner P. Overexpression of id-1 protein is a marker for unfavorable prognosis in early-stage cervical cancer. Cancer Res. 2001;61(15):5703-6.

25. Singh J, Murata K, Itahana Y, Desprez PY. Constitutive expression of the id-1 promoter in human metastatic breast cancer cells is linked with the loss of nf-1/rb/hdac-1 transcription repressor complex. Oncogene. 2002;21(12): 1812-22. https://doi.org/10.1038/sj.onc.1205252.

26. Torre LA, Bray F, Siegel RL, Ferlay J, Lortet-Tieulent J, Jemal A. Global cancer statistics, 2012. CA Cancer J Clin. 2015;65(2):87-108. https://doi.org/10.3322/ caac.21262.

27. Vicent S, Perurena N, Govindan R, Lecanda F. Bone metastases in lung cancer. Potential novel approaches to therapy. Am J Respir Crit Care Med. 2015;192(7):799-809. https://doi.org/10.1164/rccm.201503-0440SO.

28. Wang X, Liu Y, Dai L, Liu Q, Jia L, Wang H, An L, Jing X, Liu M, Li P, Cheng Z. Foxp3 downregulation in nsclc mediates epithelial-mesenchymal transition via nf-kappab signaling. Oncol Rep. 2016;36(4):2282-8. https://doi.org/10. 3892/or.2016.5024

29. Wong YC, Wang X, Ling MT. Id-1 expression and cell survival. Apoptosis. 2004:9(3):279-89.

30. Wu ZZ, Chen LS, Zhou R, Bin JP, Liao YL, Liao WJ. Metastasis-associated in colon cancer-1 in gastric cancer: beyond metastasis. World J Gastroenterol. 2016;22(29):6629-37. https://doi.org/10.3748/wjg.v22.129.6629.

31. Yap WN, Zaiden N, Tan YL, Ngoh CP, Zhang XW, Wong YC, Ling MT, Yap YL. Id1, inhibitor of differentiation, is a key protein mediating anti-tumor responses of gamma-tocotrienol in breast cancer cells. Cancer Lett. 2010; 291 (2):187-99. https://doi.org/10.1016/j.canlet.2009.10.012.

32. Zhang $X$, Ling MT, Wang $X$, Wong $Y C$. Inactivation of id- 1 in prostate cancer cells: a potential therapeutic target in inducing chemosensitization to taxol through activation of jnk pathway. International journal of cancer. J Int Cancer. 2006;118(8):2072-81. https://doi.org/10.1002/ijc.21592.

\section{Submit your next manuscript to BioMed Central and we will help you at every step:}

- We accept pre-submission inquiries

- Our selector tool helps you to find the most relevant journal

- We provide round the clock customer support

- Convenient online submission

- Thorough peer review

- Inclusion in PubMed and all major indexing services

- Maximum visibility for your research

Submit your manuscript at www.biomedcentral.com/submit
Biomed Central 